\title{
Report on the development of strategies for market penetration
}

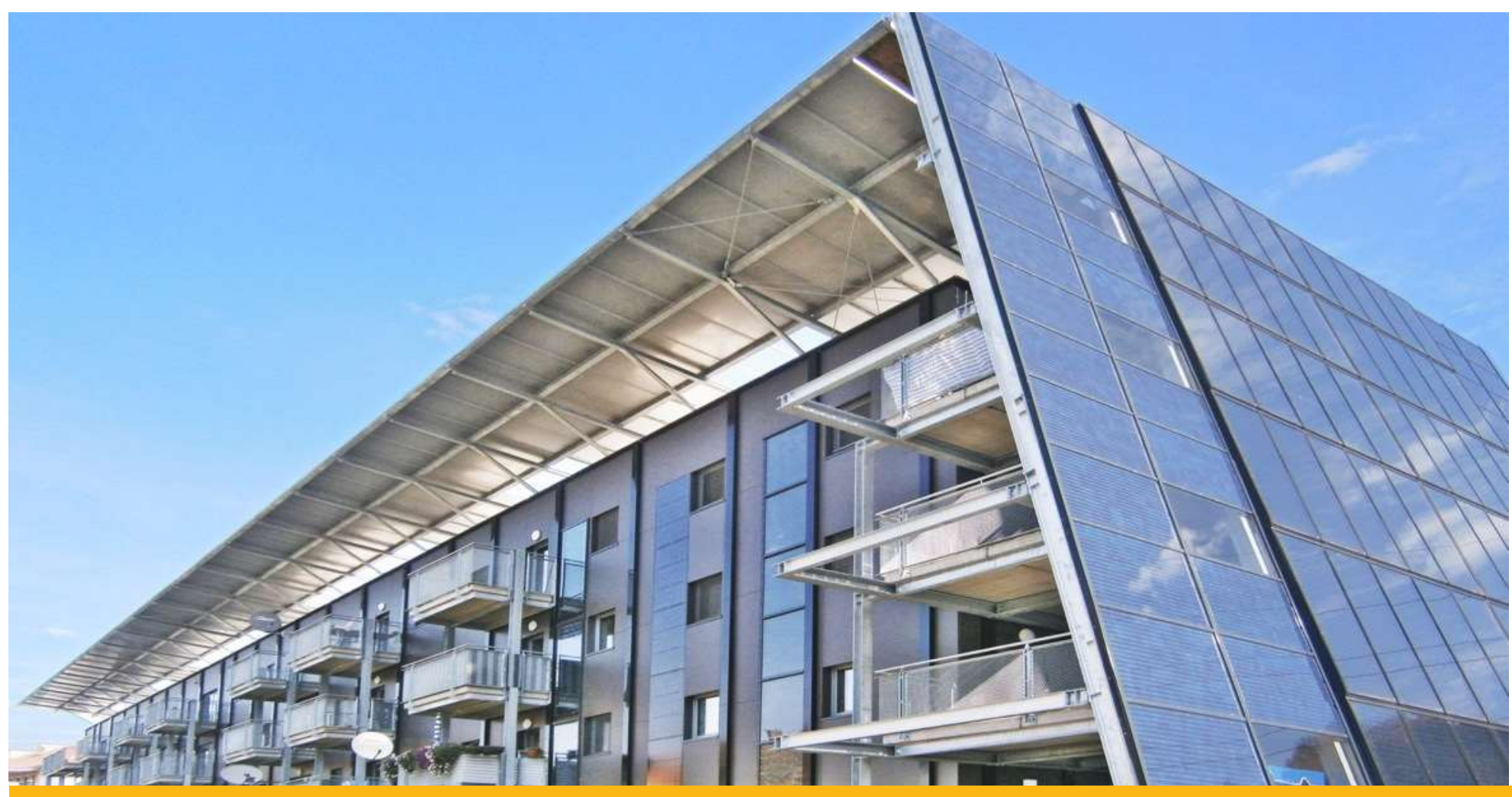

IEA SHC TASK 56 | Building Integrated Solar Envelope Systems for HVAC and Lighting 


\title{
Report on the development of strategies for market penetration
}

\author{
Deliverable DB.2
}

Editor: Christoph Maurer (Fraunhofer ISE) and Bruno Bueno (Fraunhofer ISE)

Authors (in alphabetical order):

Carolin Hubschneider (Fraunhofer IBP)

Christoph Maurer (Fraunhofer ISE)

John Hollick (SolarWall)

Michaela Meir (Aventa)

Philippe Lemarchand (DIT)

Roberto Garay (Tecnalia)

Tilmann E. Kuhn (Fraunhofer ISE)

Vickie Aagesen (Cenergia, part of Kuben Management)

\section{April, 2020}

DB.2, DOI: 10.18777/ieashc-task56-2020-0001

The contents of this report do not necessarily reflect the viewpoints or policies of the International Energy Agency (IEA) or its member countries, the IEA Solar Heating and Cooling Technology Collaboration Programme (SHC TCP) members or the participating researchers. 


\section{IEA Solar Heating and Cooling Technology Collaboration Programme (IEA SHC)}

The Solar Heating and Cooling Technology Collaboration Programme was founded in 1977 as one of the first multilateral technology initiatives ("Implementing Agreements") of the International Energy Agency. Its mission is "To enhance collective knowledge and application of solar heating and cooling through international collaboration to reach the goal set in the vision of solar thermal energy meeting $50 \%$ of low temperature heating and cooling demand by 2050."

The members of the IEA SHC collaborate on projects (referred to as Tasks) in the field of research, development, demonstration (RD\&D), and test methods for solar thermal energy and solar buildings.

Research topics and the associated Tasks in parenthesis include:

- $\quad$ Solar Space Heating and Water Heating (Tasks 14, 19, 26, 44, 54)

- Solar Cooling (Tasks 25, 38, 48, 53)

- Solar Heat for Industrial or Agricultural Processes (Tasks 29, 33, 49, 62, 64)

- Solar District Heating (Tasks 7, 45, 55)

- Solar Buildings/Architecture/Urban Planning (Tasks 8, 11, 12, 13, 20, 22, 23, 28, 37, 40, 41, 47, 51, 52, 56, $59,63)$

- $\quad$ Solar Thermal \& PV (Tasks 16, 35, 60)

- Daylighting/Lighting (Tasks 21, 31, 50,61)

- Materials/Components for Solar Heating and Cooling (Tasks 2, 3, 6, 10, 18, 27, 39)

- $\quad$ Standards, Certification, and Test Methods (Tasks 14, 24, 34, 43, 57)

- $\quad$ Resource Assessment (Tasks 1, 4, 5, 9, 17, 36, 46)

- Storage of Solar Heat (Tasks 7, 32, 42, 58)

In addition to our Task work, other activities of the IEA SHC include our:

$>$ International Conference on Solar Heating and Cooling for Buildings and Industry

$>$ SHC Solar Academy

$>$ Solar Heat Worldwide annual statics report

$>$ Collaboration with solar thermal trade associations

\section{Country Members}

Australia

Austria

Belgium

Canada

China

Denmark

European Commission

\section{Sponsor Members}

European Copper Institute International Solar Energy Society

EACREEE

$\begin{array}{ll}\text { France } & \text { South Africa } \\ \text { Germany } & \text { Spain } \\ \text { Italy } & \text { Sweden } \\ \text { Netherlands } & \text { Switzerland } \\ \text { Norway } & \text { Turkey } \\ \text { Portugal } & \text { United Kingdom }\end{array}$

ECREEE

RCREEE

SACREEE

For more information on the IEA SHC work, including many free publications, please visit www.iea-shc.org 


\section{Contents}

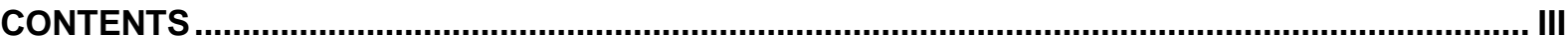

1 INTRODUCTION........................................................................................................................ 1

2 STRATEGIES FOR THE PRESENT .............................................................................. 2

3 STRATEGIES REGARDING FUTURE CHANGES ........................................................ 4

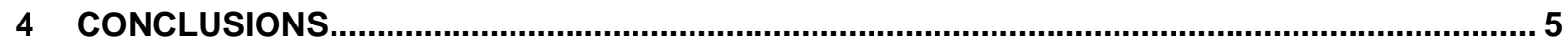

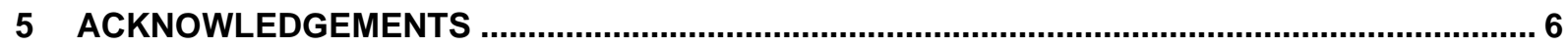

6 REFERENCES................................................................................................................... 7

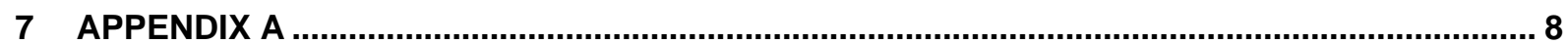




\section{Introduction}

Task 56 is part of the Solar Heating and Cooling Programme (SHC) of the International Energy Agency (IEA). Within Task 56, Subtask B aims to develop tools and strategies to foster the market penetration for industrialised solar envelope systems. This report outlines strategies for stakeholders of solar building envelopes (SBE) in order to deal with some of the market barriers that have been identified in a previous report (DB.1). The current report focuses on strategies for SBE manufacturers but includes strategies for other SBE stakeholders such as policy makers, architects, building owners and industry associations. In section 2, strategies are discussed to enhance the commercial success of SBE technologies in the current market situation. Section 3 then discusses strategies with regard to future changes in legal frameworks and boundary conditions. A summary of the proposed strategies is presented at the end. 
$>$ Focus on the additional benefits from SBE technologies (not only solar energy yield). Manufacturers should focus on the multi-functionality of SBE technologies, as well as on their influence on the physical environment of the user. Many psychological studies show that the indoor environment (illumination, temperature, humidity and acoustics) can influence the productivity of building occupants [1]. Transferred to office buildings or other buildings of the service sector, this means that e.g. poor air quality, insufficient lighting or too high temperatures can reduce work performance or even increase absence due to sickness. On the other hand, a sufficient access to daylight can improve the sleep quality of employees and a good ventilation system can increase work performance. Examples of such multifunctional products are e.g. blinds with vertical slats with integrated PV or ST functionality. With regard to the cost structure of a company, more than $90 \%$ of a company's operating costs are related to employees, while the share of building related costs is about $10 \%$ (rent and energy) [2]. As recent research shows, the building's façade and technical equipment can help to increase the productivity of its occupants. Therefore, for SBE systems that can improve the daylighting quality, the ventilation or the temperature in a building, human centric indoor environment can be a "going to market strategy".

$>$ Offer holistic design and execution packages. SBE technologies are intrinsically holistic systems, designed for multi-functional performance. It is a common situation in many integrated systems that weather protection, thermal insulation, and solar energy harvesting are performed by the same system. For the case of solar systems, the collected solar energy is then transferred to other subsystems in the building such as electric or hydronic networks. Thus solar systems implicitly require the cooperation of many stakeholders in the design, manufacture and construction processes of buildings. Over the years, processes in the construction industry have been heavily hierarchized, categorized and standardized. This process has been driven by many factors. Two of these are considered critical: 1) the atomization of specialist contractors, and 2 ) the need for budget control in public procured buildings. The atomization of contractors is commonly related to the specialization on specific tasks (i.e. excavation works, concrete works, steel structures, etc.). Because of this atomization, many contractors are not financially viable to take full responsibility of large construction sites. Partly due to the need to subcontract specific works to different contractors, economic assessments of construction projects are divided in different budget items. A hierarchized structure is developed where unitary prices (e.g. cost $/ \mathrm{m} 3$ of concrete) and specific amounts are listed. In many countries, standardized criteria have been developed for the definition of item hierarchies in budgets. Being part of different budget items and construction specialties, SBE systems conflict with the aforementioned scheme. Building integrated solar systems are at the same time part of the building envelope and of its electrical and/or HVAC networks. By SBE systems, the architectural design, conceptual HVAC design, façade engineering \& HVAC sizing is performed iteratively. This generates new opportunities based on innovative business models and partnerships between companies.

$>$ Select good reference projects. As SBE are still a niche market, building owners tend to be concerned about possible risks: what the worst-case scenario would be, what kind of problematics regarding this specific SBE can arise and why the SBE should be chosen instead of a standard envelope solution. It is important that the building owner is well informed on how the SBE is working regarding daily operation and maintenance and what they should be able to expect and require from the general performance of the SBE. The demonstration project "Lykkebo School" is a one classroom demonstration of a decentral ventilation unit with inlet and outlet integrated in the window (the demonstration project is further descripted in Appendix A). Normally, a central ventilation solution is preferred for school buildings. However, this solution demands the implementation of large ducts in the whole building and has a number of problems, which can be mitigated with decentralized ventilation systems. The situation in Copenhagen is that there are many multi-storey brick schools from around 1890 to 1940, which have poor indoor climate. The demonstration at Lykkebo school could be used as lighthouse project for many other schools in a similar situation. The project counted with the engagement and support of the janitor/facility manager. He helped choosing a suitable classroom, highlighting the general technological and indoor climate problems the school has, and informing and getting quick feedback from the class teacher. The janitor was a key person in getting the demonstration project approved by the rector of the school. This exemplifies the importance of cooperating with key persons in the project, who can ensure a successful strategy for the market.

$>$ Work out case studies with satisfactory economic assessments. Sometimes it is difficult for companies without extensive SBE experience to quantify the benefits of a SBE technology for many different cases, especially at the early stages of building projects. Economic assessments are the key to most business decisions. It is therefore recommended for SBE companies to prepare examples of life-cycle calculations (see e.g. [3]), which can be adapted to the specific situation of their clients. It is important to choose good reference cases, because the multi-functionality of SBE can prove their benefits only if all relevant differences between the SBE and the reference case are included. For example, if a building will be anyway refurbished, the option of using a SBE may involve little extra cost but lead to reduced annual costs. 
> Offer a customizable architectural appearance to be able to comply with differing aesthetic

requirements. Regarding the aesthetics of SBE, there are no general rules of what is preferred by architects, public authorities, building owners or occupants. Therefore, manufacturers should offer flexibility in the aesthetics of SBE products. This makes it easier for architects to design buildings and for building owners to approve it. There are some criteria (see e.g. [4]) that can be used to evaluate the aesthetics of SBE technologies. These criteria can also be weighted with the visibility of SBE areas to support urban planning strategies of municipalities [5]. As the building envelope is the "face" of a building, SBE manufacturers can aim to satisfy highest aesthetic demands. On the other hand, if a SBE manufacturer aims at the lowest cost, market segments should be targeted in which the aesthetic quality has a low priority, for example in some factories.

$>$ Be aware of boundary conditions (especially the conventional prices for electricity and gas). Companies should also pay attention to the specific boundary conditions of countries, where the prices of electricity and gas can vary significantly. This has a direct impact on the chances of success of some SBE technologies. The same is true for companies of different sizes in some countries. For example in Germany, small or medium size companies (SMEs) often pay high electricity prices (typically $>20 €$ cent $/ \mathrm{kWh}$ ), whereas large international companies can get special contracts with utilities with very low prices (typically < 8 €cent / kWh). CO2 savings may also become financially more attractive by regulations such as emission trading. This means that technologies that are currently not economic could become commercially attractive as soon as the cost of emitting CO2 increases significantly. Based on similar considerations, it can be reasonable to prepare plans for a rapid increase in production.

Manufacturers and installers should also focus on markets, which involve appropriate solar programs that promote solar installations and support the financing.

$>$ Take advantage of mandatory planning steps as entry points for new ideas. For example, new buildings in Denmark have to prove an energy use below the thresholds established at the "Energy frame BR". The "Energy frame BR 2015" is the lowest threshold at this moment and is replaced by "Energy frame BR 2020" in 2020. To achieve the low energy demands for the new buildings it is possible to install RES for up to 10 $\mathrm{kWh} / \mathrm{m}^{2} / \mathrm{yr}$. The renewable energy produced above this limit does not improve the rating within this regulation. This means that some building owners may not see the advantage of installing more RES into their buildings than this limit. In earlier versions of the energy calculation, it was possible to achieve a zeroenergy house with a larger area of RES. Despite the limited accountability of the yields in the energy balance of buildings, a larger PV-system or ST-system is nevertheless advisable for many building owners, since larger RES are generally more cost-effective than smaller ones. It is therefore crucial for installers and manufacturers to clarify that, in many cases, the limit in the regulation does not correlate with the optimal size. As another example, the city of Tübingen, Germany, has issued a rule for which a PV installation of 1 $\mathrm{kWp}$ is mandatory for new buildings. Practical experience shows that this obligation effectively leads to larger PV installations, because when the building owner gets involved in planning the PV system, he/she realizes that larger systems are more profitable. As a result, in Tübingen, almost all systems cover more than $50 \%$ of the useable area.

$>$ Invest in materials with good life-cycle scores. Life-cycle analysis (LCA) is normally not a triggering selling point in nowadays SBE. However, if the regulations change and subsidies become dependent also on the grey energy demand of a construction project, this situation will change. It can therefore be a strategy for SBE manufacturers to choose materials and processes that involve a small amount of grey energy. Until then, LCA results may be used as an additional argument that may be helpful in some market segments such as single family houses or building projects with sustainability certificates like LEED, BREEAM, and DGNB. 
$>$ Promote specialized education and training on SBE technologies. Few constructors will offer renewables on projects that are already tendered with conventional building energy systems. Therefore, it is up to the building planners and designers to clearly specify which renewable energy system to be installed. For this, it is important that the design community is educated on ways to integrate renewable energy into their building designs. Manufacturers can focus on convincing the designers to incorporate building integrated renewables into their early designs and specifications.

Especially for building integrated solar thermal (BIST) systems, façade construction crews need to be briefed in the installation of hydronic networks and accessories. Liaison with plumbing \& HVAC construction companies is needed for the correct construction, reception tests, and servicing of BIST systems. Successful Building Integrated Systems need to facilitate a cooperative environment for the integrated design of building envelopes, and train a set of construction contractors where communication among the construction of different items is ensured, thus allowing for the satisfactory completion of construction works dealing with solar building envelopes.

Another strategy is to carefully select and train sales teams so that they understand all potential benefits of SBE technologies, the characteristics of the markets they are operating in and the gains and pains of the costumers.

$>$ Remove additional legal barriers for SBE products. Building-integrated products may be subject to a higher level of legal approvals. For example, in France, all materials that become part of a building are required to have an "Avis Technique", which indicates to the building community that the product has been approved by an independent review board and meets certain criteria. Without an "Avis Technique", insurance companies may not insure the building. Manufacturers must be aware of these additional country specific approvals and invest the time and resources to obtain those approvals. In Germany, unglazed solar thermal systems are not eligible for incentives and have thereby been excluded from providing renewable solar heating in many cases. Another example for such national barriers are glass-glass BIPV-modules which are qualified as laminated safety glasses according to the respective harmonized European standards and construction products regulation. As CE-marked European products, they can be marketed everywhere in the European Union, but they may have to pass additional tests before they can be applied in a specific building for a specific purpose. For example, in Germany, laminated safety glass requires extra tests when it is used as fall protection barriers.

Policy-makers should address these barriers and make it easier to obtain approvals for building-integrated renewable energy systems. The implementation of the Revised Renewable Energy Directive [6] might be of great help, at least in Europe.

$>$ Improve the regulations for sharing renewable energy. Current regulations can be a barrier for example when one building produces more photovoltaic energy than it needs. The costs which are involved when trying to sell this energy to the neighbouring buildings is often high due to the regulations. In case the apartments of one building are owned by several owners, it can be too expensive to organize that the renewable energy produced by the building envelope is shared between the owners and tenants. However, it would be beneficial to share renewable energy both from an environmental and economic point of view. The revised Renewable Energy Directive from the EU puts the consumer at the centre of the energy transition with a clear right to produce own renewable energy. Regulations must be modified to make it possible.

$>$ Public funding to develop reliable evaluation methods and to generate good reference cases. Decision makers must put in place actions that support solar energy production, energy efficiency, daylight and visual comfort. Public authorities should support the development of evaluation methods, which allow stakeholders to estimate the benefits of SBE technologies in the early stages of a project. For example, building owners and planners would greatly benefit from extended solar cadasters. Google, many municipalities and other NGOs provide solar maps online, which can be used to identify promising areas for solar building envelopes (e.g. www.kk.dk/solceller). These solar cadasters should be extended to include façades and to analyse the potential of different technologies (e.g. solar thermal and PV). Likewise, public authorities should promote independent monitoring of SBE in order to prove their performance and increase the trust in these technologies. Support by decision-makers to make public buildings available to these technologies could play an important role in promoting the adoption of solar envelope solutions in both the public and private sectors.

> Lobby for SBE technologies. Industry associations and scientific communities related to SBE should lobby government agencies at all levels to implement purchasing requirements for renewable energy solutions to reduce carbon emissions. If the costs of greenhouse gas emissions are included in prices, the market can become sustainable.

If the building owners expect the energy costs to increase in the future, for example by increased taxes on fossil fuels, it is more likely that they choose sustainable solutions. This means for politicians that not only such regulations are needed, but also that they should be announced in advance. 


\section{Conclusions}

This report outlines strategies for stakeholders of solar building envelopes (SBE) to enhance the market penetration of these technologies and systems. It classifies the strategies in two group: 1) what can be done now, with current legal frameworks and boundary conditions, and 2) what can be done in the future to make more favourable these frameworks and boundary conditions. The report focuses on strategies for SBE manufacturers but includes strategies for other SBE stakeholders such as policy makers, architects, building owners and industry associations. The proposed strategies are summarized here:

1. Strategies for the present

- $\quad$ Focus on the additional benefits from SBE technologies (not only solar energy yield)

- Offer holistic design and execution packages

- $\quad$ Select good reference projects

- Work out case studies with satisfactory economic assessments

- Offer a customizable architectural appearance to be able to comply with differing aesthetic requirements

- Be aware of boundary conditions (especially the conventional prices for electricity and gas)

- Take advantage of mandatory planning steps as entry points for new ideas

- Invest in materials with good life-cycle scores

\section{Strategies for future changes}

- Promote specialized education and training on SBE technologies

- Remove additional legal barriers for SBE products

- Improve the regulations for sharing renewable energy

- Public funding to develop reliable evaluation methods and to generate gut reference cases

- Lobby for SBE technologies 


\section{Acknowledgements}

This work was partially funded by the German Federal Ministry for Economic Affairs and Energy (BMWi), based on a decision by the German Bundestag. 


\section{References}

[1] J. Alker, M. Malanca, C. Pottage, R. O'Brien, Health, Wellbeing \& Productivity in Offices: The Next Chapter for Green Building,2014.

[2] N.I.M. Makes, F. Sense, The Economics of Biophilia,2012.

[3] C. Maurer, C. Cappel, T.E. Kuhn, Progress in building-integrated solar thermal systems, in: Elsevier (Ed.), Progress in Solar Energy, 2017, http://doi.org/10.1016/j.solener.2017.05.065.

[4] Munari Probst, M. C., C. Roecker, Towards an improved architectural quality of building integrated solar thermal systems (BIST), Sol Energy 81 (9) (2007) 1104-1116, http://doi.org/10.1016/j.solener.2007.02.009.

[5] P. Florio, C. Roecker, M.C. Munari Probst, Urban acceptability of solar installations: LESO-QSV GRID, a software tool to support municipalities,2015, http://doi.org/10.5075/epfl-cisbat2015-981-986.

[6] DIRECTIVE (EU) 2018/2001 OF THE EUROPEAN PARLIAMENT AND OF THE COUNCIL of 11 December 2018 on the promotion of the use of energy from renewable sources. Official Journal of the European Union 2018. 


\section{Appendix A}

IEA SHC Task 56, Solar Envelopes

\begin{tabular}{|l|l|}
\hline Project Name & Lykkebo skole (Lykkebo school) \\
\hline Project Acronym & - \\
\hline Organization & Cenergia - a part of Kuben Management \\
\hline
\end{tabular}

\section{Geometry and boundary conditions}

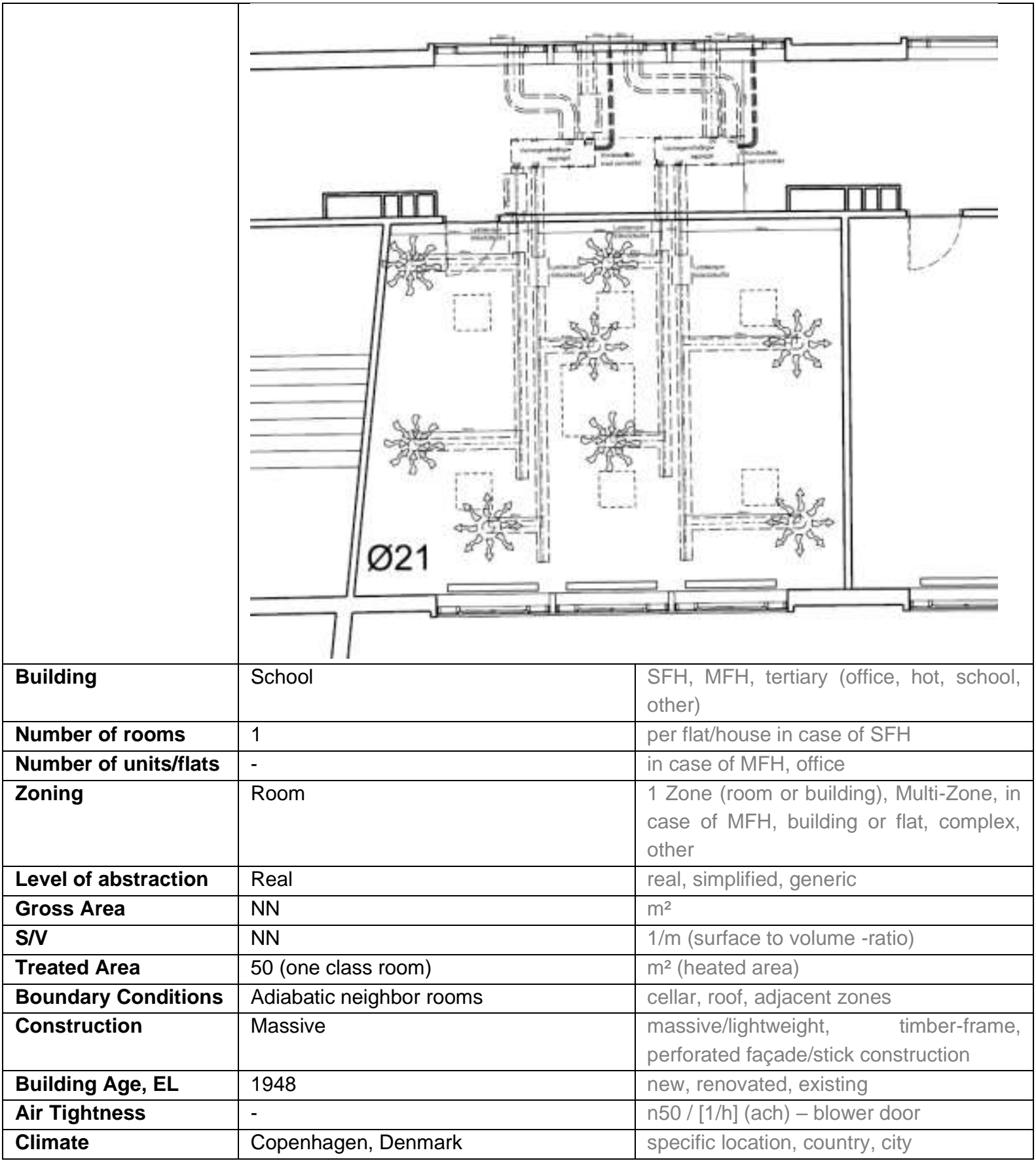


Energy demand and building operation

\begin{tabular}{|c|c|c|}
\hline Energy demand & 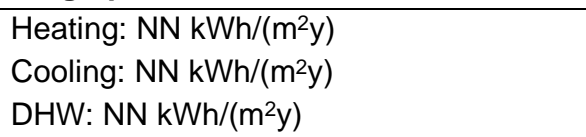 & $\begin{array}{l}\text { specific heating, cooling and DHW } \\
\text { demands / }\left[\mathrm{kWh} /\left(\mathrm{m}^{2} \mathrm{a}\right)\right]\end{array}$ \\
\hline Set point temperature & $\begin{array}{l}\text { Heating: } \mathrm{T}_{\text {op }} 20^{\circ} \mathrm{C}(22 \mathrm{C}) \\
\text { Cooling: } \mathrm{T}_{\text {op }} 27^{\circ} \mathrm{C} \\
\text { DHW: } \mathrm{T}_{\text {flow }} 55^{\circ} \mathrm{C}\end{array}$ & $\begin{array}{l}\text { SP for heating / cooling / } \\
\text { (operative/convective) dehumidification; } \\
\text { shading, glare }\end{array}$ \\
\hline $\begin{array}{l}\text { Occupation/internal } \\
\text { gains }\end{array}$ & $\begin{array}{l}28 \text { students and } 2 \text { teachers per } \\
\text { classroom }\end{array}$ & m²/Person, flat or profile,... \\
\hline DHW profile & - & ErP, flat, DHWcalc, etc. \\
\hline Energy Certificate & - & $\begin{array}{l}\text { Can you provide an Energy Certificate, } \\
\text { PHPP, other certification calculation? }\end{array}$ \\
\hline $\begin{array}{l}\text { Benchmark } \\
\text { Reference System }\end{array}$ & $\begin{array}{l}\text { reference system with central MVHR, } \\
\text { central HP }\end{array}$ & $\begin{array}{l}\text { specify if applicable the reference system } \\
\text { (e.g. air-to-water HP) }\end{array}$ \\
\hline
\end{tabular}

Technology : Ventilation and Energy system, RES

\begin{tabular}{|c|c|c|}
\hline Useful energy & Heat (District heating) & Heat, Cold, DHW, Electricity, Light \\
\hline Ventilation & $20 \mathrm{~m}^{3} / \mathrm{h} /$ person, MVHR & 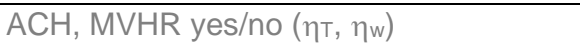 \\
\hline Generation & MVHR & $\begin{array}{l}\text { HVAC: HP, MVHR, (day-) lighting, } \\
\text { shading, glare protection, other }\end{array}$ \\
\hline Heat / Cold Emission & $\begin{array}{l}\text { Radiators and heat recovery from the } \\
\text { ventilation }\end{array}$ & $\begin{array}{l}\text { Radiator, Floor Heating, Radiant Ceiling, } \\
\text { Fan-Coil }\end{array}$ \\
\hline $\begin{array}{lll}\text { Heat } \quad / & \text { Cold } \\
\text { Distribution } & \end{array}$ & Air (MVHR) and water (District heating) & $\begin{array}{l}\text { air, water (2 pipe, } 4 \text { pipe, } 6 \text { pipe, } \\
\text { circulation) }\end{array}$ \\
\hline DHW preparation & Combined with the district heating system & relevant, combined with heating, separate \\
\hline DWH distribution & Decentral & Central, decentral, storage, etc. \\
\hline RES & - & ST, PV, PVT, other \\
\hline Façade integration & MVHR & BIPV, BIST, other \\
\hline
\end{tabular}

Numerical modelling issues

\begin{tabular}{|l|l|l|}
\hline Simulation Platform & - & $\begin{array}{l}\text { E+, TRNSYS, IDA ICE, Matlab/Simulink, } \\
\text { other }\end{array}$ \\
\hline special software & - & Co-Simulation, e.g. Comsol, Contam \\
\hline $\begin{array}{l}\text { Detailed Component } \\
\text { Study }\end{array}$ & - & $\begin{array}{l}\text { FD, FE Model, thermal, hygrothermal } \\
\text { simulation, CFD, ray tracing, other }\end{array}$ \\
\hline Time Step & - & $\begin{array}{l}\text { Monthly, Hourly, 15 min, 10 min, 5min, } \\
\text { other }\end{array}$ \\
\hline Optimization & - & \begin{tabular}{l} 
i.e. control, dimensioning, PE reduction \\
\hline
\end{tabular}
\end{tabular}

Type of analysis /Performance, Air quality, comfort indicators

\begin{tabular}{|l|l|l|}
\hline Energy Performance & $\begin{array}{l}\text { No, only the electricity for the ventilation } \\
\text { unit }\end{array}$ & yes/no \\
\hline Primary Energy & $\begin{array}{l}\text { No, only the electricity for the ventilation } \\
\text { unit }\end{array}$ & $\begin{array}{l}\text { yes/no } \\
\text { noise }\end{array}$ \\
\hline Indoor Air Quality & No & $\begin{array}{l}\text { yes, no; operative temperature, rel. } \\
\text { humidity, draught, } \Delta T_{\text {asym }} \text { etc. }\end{array}$ \\
\hline Thermal comfort & No & yes/no \\
\hline Visual comfort & No & Life Cycle Analysis \\
\hline LCA & No & Life Cycle Cost (economic optimization) \\
\hline LCC &
\end{tabular}

Others

\begin{tabular}{|l|l|l|}
\hline Monitoring & Yes & yes/no - specify monitoring system \\
\hline Remarks & & \\
\hline
\end{tabular}

